After the grafting procedure, all rats remained healthy and gained weight.

\section{DISCUSSION}

Transplantation of normal rat liver into Gunn rat liver was associated with a decrease in total serum bilirubin concentration (Table 1). This is probably due to factors other than the grafting of Wistar rat liver tissue, because the serum bilirubin concentrations similarly decreased in sham-operated rats as well.

Histologic examination revealed that the grafted tissue disappears, as reported by Mukherjee and Krasner (3); however, UDPGT activity (bilirubin), UDPG glucosyl transferase activity (bilirubin), and bile analysis failed to reveal evidence of bilirubin glucuronide or bilirubin glucoside formation.

The operative techniques were identical. The total amount of grafted liver tissue was $180-250 \mathrm{mg}$ whereas, in the earlier study (3), transplanted plugs of liver tissue weighed 200-250 mg.

\section{SUMMARY}

Grafting of liver from normal Wistar rats into the liver of homozygous Gunn rats did not result in hepatic UDPGT activity in recipient rats or in the presence of bilirubin glucuronide in their bile.

1. Gunn, C. H.: Hereditary acholuric jaundice. J. Hered., 29: 137 (1938).

2. Heirwegh, K. P. M., Van Hees, G. P., Leroy, P., Van Roy, F. P., and Jansen, F. $\mathrm{H}$.: Heterogeneity of bile pigment conjugates as revealed by chromatography of their ethyl anthranilate azo pigments. Biochem. J., 120:877 (1970).

3. Jansen, P. L. M., and Henderson, P. T.: Influence of phenobarbital treatment on $p$-nitrophenol and bilirubin glucuronidation in Wistar rat, Gunn rat and cat. Biochem. Pharmacol, 21: 2457 (1972).

4. Jansen, P. L. M., and Arias, I. M.: Delipidation and reactivation of UDP glucuronyltransferase from rat liver. Biochim. Biophys. Acta, 391: 28 (1975).

5. Lowry, O. H., Rosebrough, N. J., Farr, A. L., and Randall, R. J.: Protein measurement with the Folin phenol reagent. J. Biol. Chem., 193: 265 (1951).

6. Malloy, H. T and Evelyn, K. A. The determination of bilirubin with the photoelectric colorimeter. J. Biol. Chem., 119: 481 (1937).

7. Mukherjee, B., and Krasner, J.: Induction of an enzyme in genetically deficien rats after grafting of normal liver. Science, 182: 68 (1973).

8. Van Roy, F., and Heirwegh, K. P. M.: Determination of bilirubin glucuronidation and assay of glucuronyltransferase with bilirubin as acceptor. Biochem. J., 107: 507 (1973).

9. This research was supported by a grant from the Commonwealth Fund and Grants AM 2019, 16281, and 17702 from the National Institutes of Health.

10. Requests for reprints should be addressed to: 1. M. Arias, M.D., Liver Research Center, Albert Einstein College of Medicine, 1300 Morris Park Ave., New York, N. Y. 10461 (USA).

11. Accepted for publication May 4, 1976.

\title{
Metabolic and Hormonal Responses to a Protein-Glucose Meal in Normal Infants and in Marasmus and Marasmic Kwashiorkor
}

\author{
GEORGE G. GRAHAM, ${ }^{(53)}$ JULIO NAKASHIMA, ROBERT G. THOMPSON, AND ROBERT M. \\ BLIZZARD \\ Instituto de Investigacion Nutricional, Miraflores, Lima, Peru and Department of Pediatrics, School of Medicine,
}

The Johns Hopkins University, Baltimore, Maryland, USA

\section{Extract}

Blood sugar and plasma free fatty acids $($ FFA), immunoreactive insulin (IR I), and growth hormone $(\mathrm{GH})$ responses to a protein-glucose meal were determined in normal infants and those with marasmus and marasmic kwashiorkor. Among the normal subjects, fasting blood sugar (BS), peak BS and IRI, and the IRI/BS ratio tended to decrease as age increased. Peak IRI was at least $13 \mu \mathrm{U} /$ $\mathrm{ml}$ above fasting in 21 of 24 infants. Fasting GH levels were high, $38.5 \pm 13.6$ (SD) and $26.3 \pm 14.0 \mathrm{ng} / \mathrm{ml}$, in the two youngest groups (under 1 year) and were comparable with those of the late newborn period. They were slightly lower, $20.8 \pm 22.1$, in those 12.5-18.5 months of age. Suppressions of FFA and subsequent rebounds were in close temporal relation to $B S$ and IRI peaks and lows, but not the GH levels. GH was promptly suppressed by the meal, and in most infants secondary elevations were seen.

Untreated marasmic infants had normal or low BS, correspond- ingly normal or low IRI, markedly elevated FFA $(1,821 \pm 588$ $\mu \mathrm{Eq} /$ liter), and GH levels comparable with those of the control subjects. There was some delay in BS elevation and disappearance and poor insulin release after the meal, with only two of nine having elevations of at least $13 \mu \mathrm{U} / \mathrm{ml}$. The BS elevations and IRI responses, however, were adequate to block $F F A$ release. GH levels were poorly suppressed by the meal but some infants had further elevations, possibly in response to protein. After partial rehabilitation, fasting BS and FFA and BS elevations after the meal were normal. A slight improvement in insulin release was apparent. Fasting GH levels and responses to the meal were normal.

Fasting, minimally treated children with marasmic kwashiorkor (MK) had normal or low BS, normal or low IRI, normal FFA, and probably normal GH levels. There was considerable delay in BS elevation, moderately delayed glucose disappearance, and very poor or unmeasurable insulin release after the test meal; FFA and GH were poorly suppressed. After partial rehabilitation, fasting BS was 
normal, FFA levels were low $(630 \pm 163 \mu \mathrm{Eq} / \mathrm{l})$, IRI was still low, BS elevations and disappearance improved, IRI responses modestly improved, and $\mathbf{G H}$ responses were normal.

\section{Speculation}

Metabolic and hormonal responses of malnourished infants to a test meal may be appropriate for survival but not for renewed growth of lean body mass.

The altered metabolic state, distorted body composition, and retarded growth of severely malnourished infants have aroused interest in the hormonal mechanisms presumed to be involved. The poor nitrogen retentions of many of these infants, the very high energy intakes that are needed to promote weight gain and growth, and the persistently reduced lean body mass all suggest that important alterations in substrate utilization are part of the adaptation which is necessary for survival but may then hinder rehabilitation. Even when rapid weight gain is established during recovery, this may be primarily the result of fat deposition (14).

In order to better understand the mechanisms governing substrate utilization, we have measured the responses to a proteinglucose meal of the blood sugar, plasma immunoreactive insulin, plasma growth hormone, and plasma free fatty acids of infants with marasmus or marasmic kwashiorkor. Although it was recognized that impaired absorption would influence the results, and that the responses observed might not be maximal, we felt that they would be more representative of responses taking place when such infants are realimented than those to induced hyper- and hypoglycemia or to amino acid infusions $(2,4,8,11,12,14,31,39,41)$. Because of the paucity of reported normal values in infants of different ages, and because control samples handled in the sample manner as the study samples would be more meaningful, we evaluated healthy infants selected to match the study cases in age and body size.

\section{SUBJECTS}

\section{NORMAL CONTROL SUBJECTS}

Three age groups were selected for study (Table 1): $C-1$ approximated the size and $C-2$ the age of typical marasmic infants; $C-3$ approximated the size of those with MK. We did not study age controls for MK.

All control subjects and nearly all the malnourished subjects were males because of greater ease of urine collection. Nine normal subjects were studied twice, at different ages; six only once. The reasons for admission, diet, physical findings, growth pattern, and routine laboratory investigations have been described $(9,13)$.

\section{MALNOURISHED INFANTS}

Nine patients with marasmus were studied on the day after admission; seven were restudied on the 24th to 79th hospital day. Eleven patients with MK were studied on the day after admission. Ten were restudied on the 24th to 75th hospital day, one of them twice. One additional patient was first studied on the 25 th day. Their ages, heights, and weights are listed in Table 2. Results of physical examinations and routine laboratory determinations for 6

Table 1. Age, height, and weight of three groups of control subjects

\begin{tabular}{ccccc}
\hline Group & $n$ & $\begin{array}{c}\text { Age, mo } \\
\text { (range) }\end{array}$ & $\begin{array}{c}\text { Height, cm } \\
\text { (range) }\end{array}$ & $\begin{array}{c}\text { Weight, kg } \\
\text { (range) }\end{array}$ \\
\hline$C-1$ & 8 & $2.1-3.2$ & $53.2-65.0$ & $4.33-6.83$ \\
$C-2$ & 8 & $4.5-10.6$ & $61.7-72.5$ & $6.25-8.83$ \\
$C-3$ & 8 & $12.5-18.5$ & $71.6-81.8$ & $9.38-14.0$ \\
\hline
\end{tabular}

Table 2. Age, height, and weight of infants with marasmus $(M)$ or marasmic kwashiorkor $(M K)$ studied on day after admission and again when partially recovered

\begin{tabular}{|c|c|c|c|c|c|c|c|}
\hline \multirow[b]{2}{*}{$\begin{array}{l}\text { Diagnosis } \\
\text { and case }\end{array}$} & \multicolumn{3}{|c|}{ Admission study } & \multicolumn{4}{|c|}{ Convalescent study } \\
\hline & $\begin{array}{l}\text { Age, } \\
\text { mo }\end{array}$ & $\begin{array}{l}\mathrm{Ht}, \\
\mathrm{cm}\end{array}$ & $\begin{array}{l}\mathrm{Wt} \\
\mathrm{kg}\end{array}$ & $\begin{array}{l}\text { Hos- } \\
\text { pital } \\
\text { day }\end{array}$ & $\begin{array}{l}\text { Age, } \\
\text { mo }\end{array}$ & $\begin{array}{l}\mathrm{Ht} \\
\mathrm{cm}\end{array}$ & $\begin{array}{l}\text { Wt, } \\
\mathrm{kg}\end{array}$ \\
\hline$M 221$ & 6.7 & 63 & 4.15 & 24 & 7.4 & 63 & 4.69 \\
\hline$M 223$ & 6.2 & 64 & 4.70 & \multicolumn{4}{|c|}{ Died of sepsis } \\
\hline$M 225$ & 7.2 & 56 & 3.30 & 76 & 9.7 & 61 & 4.53 \\
\hline M 237 & 9.9 & 66 & 5.96 & 50 & 11.5 & 66.7 & 7.30 \\
\hline$M 265$ & 10.9 & 61 & 4.30 & 28 & 11.7 & 61 & 5.39 \\
\hline$M 283$ & 5.4 & 56.3 & 3.40 & 66 & 7.5 & 59 & 4.56 \\
\hline$M 363$ & 9.5 & 63 & 4.52 & 22 & 10.2 & 63 & 5.28 \\
\hline$M 370$ & 4.9 & 58 & 3.50 & 79 & 7.4 & 61 & 5.73 \\
\hline M 373 & 7.9 & 58 & 3.20 & \multicolumn{4}{|c|}{ Died of sepsis } \\
\hline$M K 254$ & 26.2 & 79.2 & 10.93 & 24 & 26.9 & 79.2 & 9.58 \\
\hline$M K 255$ & 23.8 & 78.5 & 8.64 & 31 & 24.8 & 78.5 & 8.35 \\
\hline$M K 257$ & 38.9 & 84.5 & 11.60 & $29^{1}$ & 39.9 & 84.5 & 10.60 \\
\hline & & & & 75 & 41.3 & 85.6 & 12.23 \\
\hline$M K 258$ & $22.5^{2}$ & 75 & 9.22 & 42 & 23.8 & 76.1 & 9.54 \\
\hline$M K 262$ & 23.5 & 78.1 & 9.10 & 31 & 24.4 & 78.5 & 9.05 \\
\hline$M K 286$ & 35.5 & 85.5 & 13.00 & 27 & 36.3 & 84.6 & 11.47 \\
\hline$M K 296$ & 24.1 & 69.8 & 6.56 & 43 & 25.5 & 70.5 & 7.80 \\
\hline$M K 347$ & 15.9 & 75 & 6.88 & \multicolumn{4}{|c|}{ Died of sepsis } \\
\hline$M K 349^{3}$ & 21.7 & 75 & 8.76 & 26 & 22.5 & 75.5 & 9.03 \\
\hline$M K 228$ & \multicolumn{3}{|c|}{ Not studied } & 41 & 37.5 & 95.5 & 14.45 \\
\hline$M K 358^{3}$ & 15.7 & 73.5 & 7.13 & 42 & 17.0 & 73.5 & 6.42 \\
\hline$M K 242$ & 39.7 & 80.5 & 13.15 & 25 & 40.5 & 80.5 & 11.43 \\
\hline
\end{tabular}

${ }^{1}$ Unsuspected pneumonia present at time of study.

${ }^{2}$ Pyodermia: blood culture + for hemolytic Staphylococcus aureus.

${ }^{3}$ Cases $M K 349$ and $M K 358$ were girls, all others boys.

of the 9 cases of marasmus and 8 of the 12 cases of MK have been published, as have details of management $(9,13)$. The additional cases had similar characteristics.

\section{METHODS}

Malnourished subjects were admitted to the hospital in the afternoon of the day before the studies. Blood was obtained for culture, electrolytes, serum proteins, and blood typing and crossmatching. Marasmic infants were given an oral dextrose-electrolyte mixture $(1.50 \mathrm{ml} / \mathrm{kg}$ body wt $/ 24 \mathrm{hr})$ until midnight and then fasted until blood was drawn at $8 \mathrm{AM}$. Those with MK, depending on the hour of admission, received one or two feedings, each providing $0.4 \mathrm{~g}$ protein (casein) and $15 \mathrm{kcal} / \mathrm{kg}$ body wt, as well as the dextrose-electrolyte mixture; both were discontinued at midnight.

Although all patients were initially presumed to be free of recent dehydrating diarrhea or severe infection, two cases of marasmus and one of MK turned out to be septic, the blood cultures on admission growing gram-negative pathogens. One case of MK had more than the usual superficial skin infection and his blood culture on admission grew hemolytic Staphylococcus aureus. Another was restudied on the 29th day, while seemingly well, but later became febrile and had pneumonitis by x-ray; he was studied again on the 75th day.

Approximately two-thirds of the malnourished subjects and most of the control subjects had up to $15 \mathrm{ml}$ of blood drawn for thyroid and adrenal hormone studies. In the malnourished subjects the same volume of fresh blood in a citrated syringe was immediately replaced. In the control subjects, volume replacement was with physiologic saline solution. In these subjects the fasting 
blood specimen for the present studies was obtained approximately $1 \mathrm{hr}$ after replacement.

Immediately after this fasting blood specimen was obtained, all subjects received a bottle feeding which provided $0.4 \mathrm{~g}$ protein (casein) and $2.0 \mathrm{~g}$ glucose $/ \mathrm{kg}$ body wt. Although fat is commonly but not invariably included in the formulas used in early dietary therapy, the amounts to be added to the test meal would have been very small; in any case, fat would not have influenced the hormonal responses (46). Blood samples were obtained 15,30,60,120, and $180 \mathrm{~min}$ after the feeding. A further 240 -min sample was taken in over half of the subjects. As each sample consisted of approximately $4 \mathrm{ml}$ of blood, all malnourished subjects had the total volume replaced with fresh blood after the last sample was obtained. The control subjects were given supplemental oral iron.

The BS was determined immediately by the Somogyi-Nelson method (35) on capillary blood obtained by heel-stick. Heparinized venous blood obtained at the same times was immediately spun down and the plasma separated. An aliquot was taken for determination of FFA (10). The balance was frozen and kept at $-20^{\circ}$ until shipped in Dry Ice to the Johns Hopkins Hospital, where it was kept frozen until determinations of IRI and GH were made $(45,47)$. Hormonal assays were carried out periodically in batches which included samples from control and malnourished infants. Admission and convalescence samples from each patient were assayed in the same batch.

When the patients had recovered from all acute manifestations and were gaining weight on an appropriate diet, 23 to 78 days after admission, they were restudied in an identical manner.

\section{RESULTS}

NORMAL INFANTS (FIG. 1)

The differences in mean fasting BS values found between the three age groups were not significant. A coefficient of correlation between fasting BS and IRI values of $0.52(P<0.02)$ suggests that the wide range of individual BS values was not due to laboratory error.

Postprandial BS curves (Fig. 1 $A$ ) were similar for the three groups. At $120 \mathrm{~min}$ the BS had fallen to or below the fasting level in 20 of 24 infants. Only two had curves indicative of some intolerance: both had normal insulin responses, and when retested, had normal glucose tolerance.

Mean fasting IRI (Fig. 1B) was similar for the three groups. Peak IRI generally coincided with, and was proportional to peak BS $(r=0.44, P<0.05)$. In 21 of 24 , peak IRI was at least 13 $\mu \mathrm{U} / \mathrm{ml}$ higher than fasting, and in 14 at least $20 \mu \mathrm{U}$ higher. Peak levels were at least $20 \mu \mathrm{U} / \mathrm{ml}$ in 21 of 24 , and $30 \mu \mathrm{U} / \mathrm{ml}$ in 15 of 24 tests. There were no unduly sustained insulin responses.

Fasting plasma FFA values were not significantly correlated with IRI or BS. They fell by $40 \%$ or more at 60 or $120 \mathrm{~min}$ in 21 of 24 (Fig. 1C) and rebounded at 180 or $240 \mathrm{~min}$. The most impressive drops were associated with the greatest BS and IRI elevations.

Mean fasting GH levels (Fig. $1 D$ ) were $38.5 \pm 13.6(\mathrm{SD}), 26.3 \pm$ 14.0 , and $20.8 \pm 22.1 \mathrm{ng} / \mathrm{ml}$ in the three age groups. In 19 of the 20 with 10.0 or more $\mathrm{ng} / \mathrm{ml}$, marked suppression was evident at 15 and even more so at $30 \mathrm{~min}$. In 7 of these 19 there was no subsequent elevation of any magnitude and in 12 a new peak was evident between 60 and $240 \mathrm{~min}$. In the one with no postprandial suppression, there was a marked rise to $60.0 \mathrm{ng} / \mathrm{ml}$ at $120 \mathrm{~min}$. Four children with fasting values below 10.0 were all over 1 year of age: three had modest postprandial elevations but it is conceivable that two of these may have been responses to the venipunctures (31). It was thus possible to demonstrate adequate $\mathrm{GH}$ secretion in 21 or possibly 23 of 24 normal infants and small children. The FFA rebounds back to fasting levels were not dependent on GH responses.
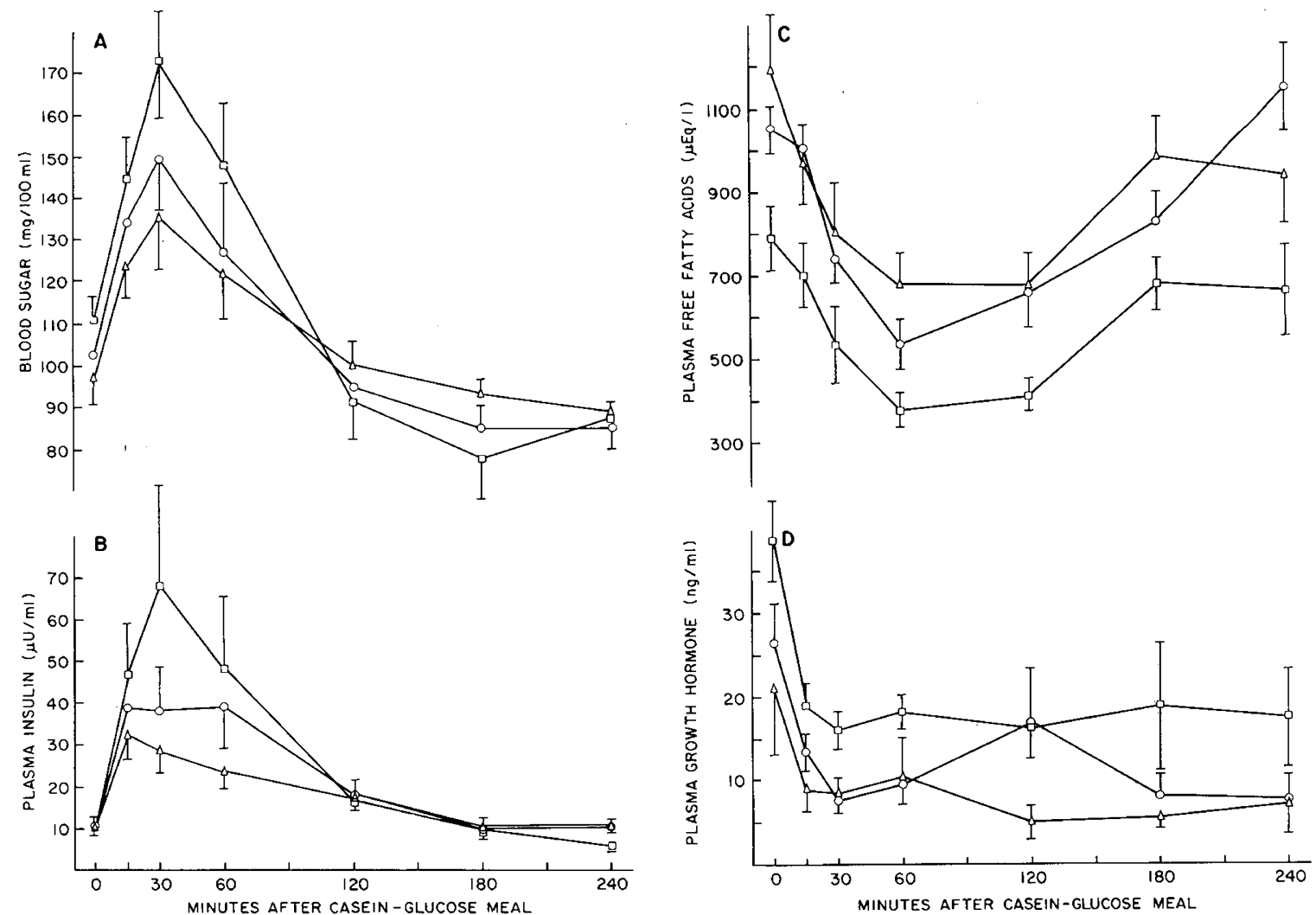

Fig. 1. Mean $( \pm \mathrm{SE})$ blood sugar $(A)$, plasma immunoreactive insulin $(B)$, plasma free fatty acid $(C)$, and plasma growth hormone $(D)$ responses of normal infants to a casein-glucose meal. Open squares $(\square)$ correspond to youngest group $(C$-l $)$, circles $(O)$ to intermediate group $(C-2)$, and triangles $(\triangle)$ to oldest group $(C-3)$. 

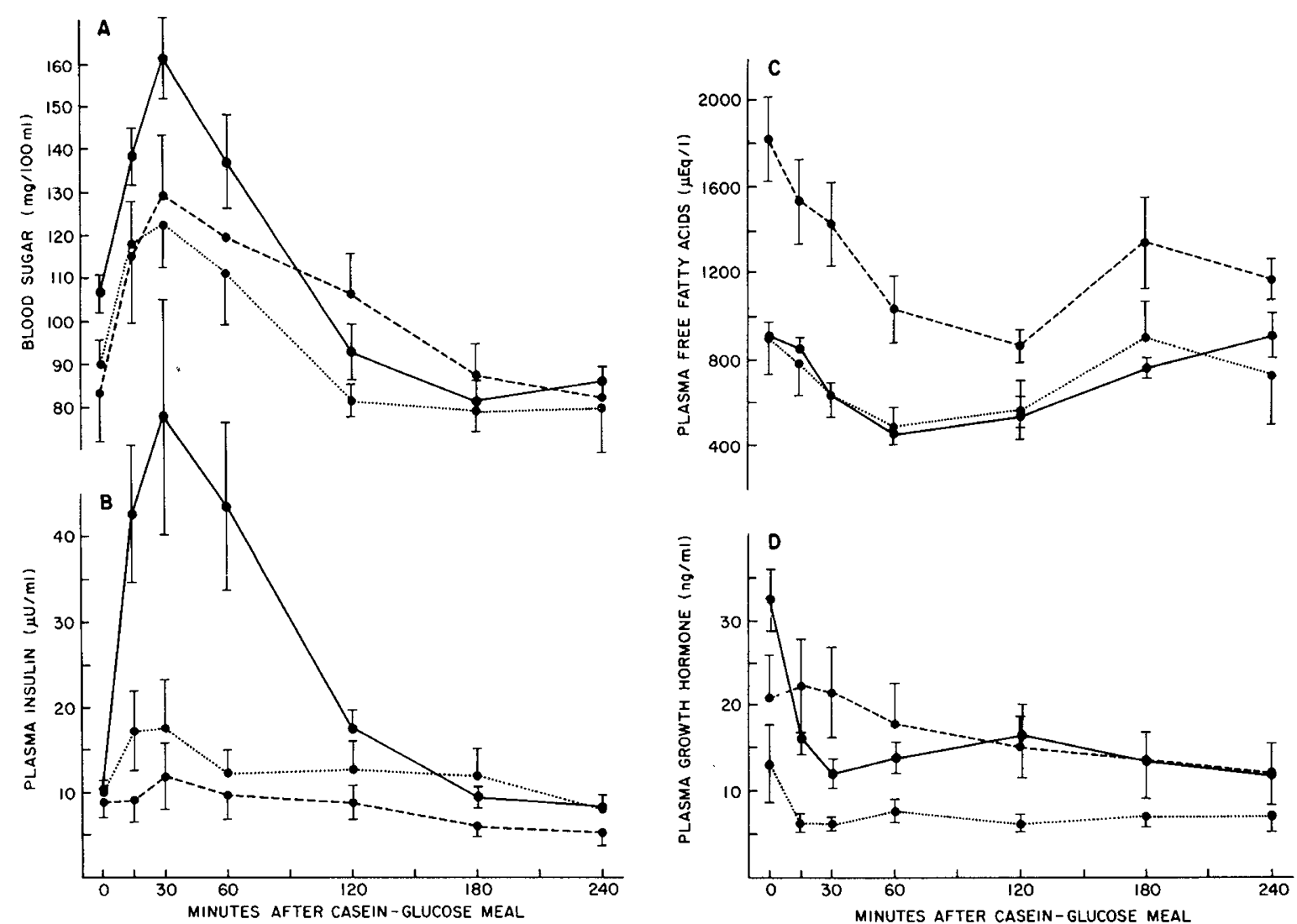

Fig. 2. Mean $( \pm \mathrm{SE})$ blood sugar $(A)$, plasma insulin $(B)$, free fatty acid $(C)$, and growth hormone $(D)$ responses of marasmic infants to a casein-glucose meal on the day after admission (- - and during convalescence $(\cdots \cdots)$, compared with those of normal infants of comparable age and size (-) Results from groups $C-I$ and $C-2$ are combined for normal values.

\section{MARASMUS}

Six of nine marasmic infants had fasting BS on admission (Fig. 2 , Table 3) which were more than 2 SD below the mean for $C-1$; three of the six were more than 2 SD's below the mean for $C-2$. The means were not significantly different. Peak BS was delayed until 60 or $120 \mathrm{~min}$ in three cases and they, as well as three others, had levels above fasting at $120 \mathrm{~min}$.

Mean fasting IRI on admission (Fig. $2 B$ and Table 3) was not significantly lower than in control subjects, although 3 subjects had levels below the sensitivity of the method. However, none of the 16 controls did so. The correlation between fasting BS and IR I was not significant. Only two infants demonstrated IRI increases of at least $13 \mu \mathrm{U} / \mathrm{ml}$ at $30 \mathrm{~min}$.

Fasting FFA levels on admission (Fig. $2 C$ and Table 3) were all higher than the highest in group $C-1$, and six of eight in $C-2$. The mean was significantly higher than that of either group. Plasma FFA fell after the meal by at least $40 \%$ in seven infants, with rebounds apparent in all. The greatest falls were associated with the highest peak BS and IRI levels. The $r$ value between peak IRI and lowest FFA was $-0.727(P<0.05)$.

Fasting $\mathrm{GH}$ on admission (Fig. $2 D$ and Table 3 ) was above 10 $\mathrm{ng} / \mathrm{ml}$ in six infants; all age or size controls had levels above this. In only one of these six was there a definite suppression postprandially, with a new peak at $180 \mathrm{~min}$. Four of the six demonstrated further elevations postprandially, while two of the three with fasting levels below $10 \mathrm{ng} / \mathrm{ml}$ also had some postprandial elevation.

After partial rehabilitation (Fig. $2 A$ and Table 3), the BS at 120 min had fallen below or close to fasting in all cases. Fasting IRI was measurable in six of seven infants (Fig. $2 B$ and Table 3); correlation with BS was poor. Two had increases of $13 \mu \mathrm{U}$ or more postprandially.

Fasting and postprandial plasma FFA in partially rehabilitated infants (Fig. $2 C$ and Table 3) was indistinguishable from that of control infants.

Fasting GH levels (Fig. $2 D$ and Table 3) were above $10 \mathrm{ng} / \mathrm{ml}$ in only three infants. All three demonstrated postprandial suppression evident at $15 \mathrm{~min}$, and probably significant secondary peaks. The remaining four had clearcut elevations at 60 or $180 \mathrm{~min}$.

\section{MARASMIC KWASHIORKOR}

Mean fasting BS before therapy (Fig. $3 A$ and Table 4) was not different from that of group $C-3$ but that at $15 \mathrm{~min}$ was significantly lower $(P<0.05)$. Peak elevations were seen from 30 to $180 \mathrm{~min}$. In 10 of 11 subjects the 120 -min value was above fasting.

Although four children had fasting IRI (Fig. 3B, Table 4) below the sensitivity of the method, the mean was not significantly lower than that of the control subjects. Only one child had an IRI elevation of more than $13 \mu \mathrm{U}$. Five had no IRI response of any magnitude, and the remaining three had very much delayed or sustained minimal responses, generally associated with poor or delayed glucose elevations. The $r$ value of 0.73 between peak BS and peak IRI was significant $(P<0.02)$.

Mean fasting FFA (Fig. $3 C$, Table 4) was not significantly different from that of the control subjects. It had not fallen appreciably by $30 \mathrm{~min}$, reached its lowest point only at $120 \mathrm{~min}$, and had not rebounded by $240 \mathrm{~min}$. Six of the 11 had FFA falls of at least $40 \%$ evident at 120 or $180 \mathrm{~min}$. The $r$ between percentage of fall in FFA and peak IRI was $-0.72(P<0.05)$. Maximum FFA fall coincided with or followed peak BS elevation in nine children.

The mean fasting GH (Fig. $3 D$ and Table 4 ) was similar to that of group C-3. Seven were above $10 \mathrm{ng} / \mathrm{ml}$, but only two demonstrated clear-cut suppression shortly after the meal, with a secondary peak. The other five had further elevations at 15 or 30 
Table 3. Blood sugar and plasma insulin, free fatty acid, and growth hormone responses of marasmic infants to a casein-glucose meal on the day after admission (I) and during convalescence (II)

\begin{tabular}{|c|c|c|c|c|c|c|c|c|c|c|c|c|c|c|}
\hline \multirow{2}{*}{ Case } & \multicolumn{7}{|c|}{ Group I } & \multicolumn{7}{|c|}{ Group II } \\
\hline & $0 \mathrm{~min}$ & $15 \mathrm{~min}$ & $30 \mathrm{~min}$ & $60 \mathrm{~min}$ & $120 \mathrm{~min}$ & $180 \mathrm{~min}$ & $240 \mathrm{~min}$ & $0 \mathrm{~min}$ & $15 \mathrm{~min}$ & $30 \mathrm{~min}$ & $60 \mathrm{~min}$ & $120 \mathrm{~min}$ & $180 \mathrm{~min}$ & $240 \mathrm{~min}$ \\
\hline & \multicolumn{14}{|c|}{ Blood sugar, $\mathrm{mg} / 100 \mathrm{ml}$} \\
\hline 221 & 61 & 69 & 79 & 79 & 71 & 80 & & 88 & 99 & 105 & 90 & 80 & 89 & \\
\hline 223 & 75 & 79 & 134 & 118 & 120 & 104 & & & & & & & & \\
\hline 225 & 54 & 136 & 162 & 204 & 163 & 60 & & 91 & 143 & 147 & 96 & 91 & 80 & \\
\hline 237 & 109 & 127 & 123 & 96 & 74 & 103 & & 73 & 121 & 108 & 91 & 89 & 84 & \\
\hline 265 & 137 & 162 & 184 & 153 & 105 & 88 & 101 & 79 & 124 & 132 & 140 & 73 & 71 & 63 \\
\hline 283 & 124 & 203 & 189 & 74 & 100 & 71 & 36 & 118 & 143 & 122 & 92 & 95 & 81 & 87 \\
\hline 363 & 78 & 98 & 93 & 115 & 89 & 62 & 66 & 71 & 67 & 84 & 96 & 68 & 56 & 62 \\
\hline 370 & 78 & 107 & 130 & 126 & 103 & 83 & 93 & 105 & 128 & 158 & 172 & 72 & 88 & 104 \\
\hline 373 & 33 & 56 & 70 & 102 & 130 & 130 & 112 & & & & & & & \\
\hline $\bar{\chi}$ & 83 & 115 & 129 & 119 & 106 & 87 & 82 & 89 & 118 & 122 & 111 & 81 & 78 & 79 \\
\hline$\hat{S} E M \quad$ ' & 11 & 16 & 15 & 14 & 10 & 8 & 14 & 7 & 10 & 10 & 12 & 4 & 4 & 10 \\
\hline \multicolumn{15}{|c|}{ Plasma insulin, $\mu \mathrm{U} / \mathrm{ml}$} \\
\hline 221 & 8.4 & 6.5 & 8.1 & 5.3 & 7.9 & 6.7 & & 8.1 & 8.9 & 8.6 & 5.4 & 6.9 & 5.6 & \\
\hline 223 & 11.9 & 7.0 & 6.0 & 8.3 & 11.5 & 6.9 & & & & & & & & \\
\hline 225 & 9.3 & & $<3.0$ & $<3.0$ & 9.0 & $<3.0$ & & 11.3 & 23.2 & 32.9 & 20.8 & 13.6 & 19.4 & \\
\hline 237 & 19.3 & 19.3 & 22.4 & 20.5 & 11.4 & 12.5 & & 15.5 & 34.8 & 39.8 & 21.5 & 25.3 & 15.2 & \\
\hline 265 & 13.8 & 10.4 & 26.8 & 23.5 & 22.0 & 6.2 & 6.9 & 14.6 & 18.4 & 8.1 & 10.0 & 14.5 & 10.2 & $<3.0$ \\
\hline 283 & 8.2 & 19.8 & 31.5 & 17.4 & 7.5 & 11.4 & 10.7 & 15.6 & 28.5 & 26.4 & 16.0 & 22.3 & 25.8 & 22.0 \\
\hline 363 & $<3.1$ & $<3.1$ & $<3.1$ & $<3.1$ & $<3.1$ & $<3.1$ & $<3.1$ & $<3.1$ & $<3.1$ & $<3.1$ & $<3.1$ & 3.5 & $<3.1$ & $<3.1$ \\
\hline 370 & $<3.1$ & $<3.1$ & $<3.1$ & $<3.1$ & $<3.1$ & $<3.1$ & $<3.1$ & 3.7 & $<3.1$ & $<3.1$ & 8.1 & 3.1 & 3.1 & 5.1 \\
\hline 373 & $<3.1$ & $<3.1$ & $<3.1$ & $<3.1$ & 3.9 & $<3.1$ & $<3.1$ & & & & & & & \\
\hline $\bar{\chi}$ & 8.9 & 9.0 & 11.8 & 9.6 & 8.8 & 6.1 & 5.3 & 10.3 & 17.1 & 17.4 & 12.1 & 12.7 & 11.8 & 8.0 \\
\hline$\widehat{\text { SEM }}$ & 1.9 & 2.5 & 3.9 & 2.8 & 2.0 & 1.3 & 1.5 & 2.0 & 4.7 & 5.8 & 2.8 & 3.3 & 3.3 & 4.7 \\
\hline
\end{tabular}

Plasma free fatty acids, $\mu \mathrm{Eq} /$ liter

\begin{tabular}{|c|c|c|c|c|c|c|c|c|c|c|c|c|c|c|}
\hline 221 & 1,762 & 1,578 & 1,447 & 1,473 & 1,184 & 1,368 & & 1,256 & 1,014 & 966 & 692 & 1,175 & 1,111 & \\
\hline 223 & 1,558 & 1,018 & 1,193 & 1,479 & 970 & 1,208 & & & & & & & & \\
\hline 225 & 3,004 & 2,649 & 2,681 & 1,744 & 1,066 & 2,778 & & 1,544 & 1,474 & 1,018 & 860 & 878 & 1,229 & \\
\hline 237 & 1,464 & 990 & 832 & 495 & 695 & 769 & & 1,058 & 892 & 552 & 359 & 248 & 1,168 & \\
\hline 265 & 2,528 & 2,243 & 1,905 & 837 & 365 & 757 & 1,495 & 830 & 764 & 589 & 382 & 556 & 1,494 & 1,129 \\
\hline 283 & 1,198 & 1,085 & 791 & 441 & 994 & 1,763 & 1,141 & 719 & 568 & 501 & 414 & 360 & 371 & 512 \\
\hline 363 & 1,394 & 1,160 & 1,112 & 809 & 741 & 1,453 & 1,073 & 618 & 437 & 470 & 533 & 586 & 660 & 1,097 \\
\hline 370 & 1,534 & 1,235 & 1,263 & 861 & 881 & 1,263 & 1,228 & 221 & 292 & 310 & 177 & 124 & 248 & 177 \\
\hline 373 & 1,947 & 1,847 & 1,591 & 1,136 & 842 & 743 & 917 & & & & & & & \\
\hline $\bar{\chi}$ & 1,821 & 1,534 & 1,424 & 1,031 & 860 & 1,345 & 1,171 & 892 & 779 & 629 & 488 & 561 & 897 & 729 \\
\hline SEM & 196 & 199 & 196 & 152 & 80 & 214 & 96 & 165 & 150 & 99 & 86 & 138 & 178 & 232 \\
\hline \multicolumn{15}{|c|}{ Plasma growth hormone, $\mathrm{ng} / \mathrm{ml}$} \\
\hline 221 & 19 & 35 & 40 & 24 & 21 & 23 & & 9 & 4.5 & 8.2 & 11 & 9.6 & 4 & \\
\hline 223 & 28 & 50 & 34 & 28 & 33 & 20 & & & & & & & & \\
\hline 225 & 3.6 & 5.4 & 5.4 & 5 & 6.6 & 2.9 & & 1.0 & 1.7 & 4.6 & 11.5 & 3.2 & 1.6 & \\
\hline 237 & 50 & 20 & 13 & 12 & 9.4 & 30 & & 17 & 8 & 6.2 & 9.8 & 5.2 & 8 & \\
\hline 265 & 9 & 4.1 & 4.5 & 5 & 4.5 & 3.6 & 8 & 14 & 9.4 & 6.4 & 9 & 9.4 & 4.5 & 10 \\
\hline 283 & 38 & 43 & 50 & 47 & 17 & 13 & 25 & 6.6 & 5.2 & 4.6 & 3.1 & 6 & 10 & 10.5 \\
\hline 363 & 4.4 & 9.3 & 8.7 & 9.2 & 6.6 & 4.2 & 8.2 & 6 & 5.8 & 4.2 & 5.1 & 3.5 & 11.6 & 3.6 \\
\hline 370 & 18.6 & 14.5 & 16 & 7.5 & 7.8 & 9.8 & 5.3 & 38.2 & 9.3 & 9.3 & 4.6 & 6.8 & 10 & 4.3 \\
\hline 373 & 16 & 19 & 21.6 & 23 & 29.7 & 16.9 & 13.4 & & & & & & & \\
\hline $\bar{\chi}$ & 20.7 & 22.3 & 21.5 & 17.9 & 15.1 & 13.7 & 12.0 & 13.1 & 6.3 & 6.2 & 7.7 & 6.2 & 7.1 & 7.1 \\
\hline SEM & 5.2 & 5.6 & 5.4 & 4.7 & 3.6 & 3.2 & 3.5 & 4.6 & 1.1 & 0.7 & 1.3 & 1.0 & 1.4 & 1.8 \\
\hline
\end{tabular}


Table 4. Blood sugar and plasma insulin, free fatty acid, and growth hormone responses of children with marasmic kwashiorkor to a casein-glucose meal on the day after admission (I) and during convalescence (II)

\begin{tabular}{|c|c|c|c|c|c|c|c|c|c|c|c|c|c|c|}
\hline \multirow{2}{*}{ Case- } & \multicolumn{7}{|c|}{ Group I } & \multicolumn{7}{|c|}{ Group II } \\
\hline & $0 \mathrm{~min}$ & $15 \mathrm{~min}$ & $30 \mathrm{~min}$ & $60 \mathrm{~min}$ & $120 \mathrm{~min}$ & $180 \mathrm{~min}$ & $240 \mathrm{~min}$ & $0 \mathrm{~min}$ & $15 \mathrm{~min}$ & $30 \mathrm{~min}$ & $60 \mathrm{~min}$ & $120 \mathrm{~min}$ & $180 \mathrm{~min}$ & $240 \mathrm{~min}$ \\
\hline & \multicolumn{14}{|c|}{ Blood sugar, $\mathrm{mg} / 100 \mathrm{ml}$} \\
\hline 254 & 57 & 62 & 75 & 70 & 83 & 85 & & 79 & 99 & 127 & 100 & 90 & 85 & \\
\hline 255 & 87 & 88 & 90 & 97 & 93 & 96 & & 76 & 89 & 113 & 82 & 92 & 79 & 87 \\
\hline \multirow[t]{2}{*}{257} & 71 & 79 & 90 & 107 & 95 & 95 & & 91 & 106 & 121 & 124 & 94 & 79 & 80 \\
\hline & & & & & & & & 92 & 116 & 121 & 126 & 100 & 78 & 82 \\
\hline 258 & 135 & 162 & 173 & 183 & 194 & 121 & 86 & 100 & 102 & 83 & 96 & 90 & 81 & 79 \\
\hline 262 & 89 & 92 & 94 & 103 & 69 & 81 & 84 & 80 & 88 & 86 & 84 & 71 & 79 & 81 \\
\hline 286 & 114 & 107 & 129 & 134 & 117 & 124 & 124 & 71 & 91 & 81 & 86 & 71 & 66 & 75 \\
\hline 296 & 88 & 103 & 106 & 117 & 131 & 120 & 118 & 76 & 104 & 142 & 116 & 72 & 77 & 81 \\
\hline 347 & 91 & 104 & 109 & 109 & 135 & 105 & & & & & & & & \\
\hline 349 & 50 & 93 & 109 & 95 & 80 & 83 & 90 & 71 & 107 & 124 & 109 & 90 & 97 & 81 \\
\hline 228 & & & & & & & & 132 & 86 & 85 & 110 & 107 & 80 & 48 \\
\hline 358 & 72 & 118 & 127 & 123 & 88 & 84 & 85 & 67 & 80 & 82 & 97 & 82 & 93 & 79 \\
\hline 242 & 68 & 77 & 87 & 108 & 89 & 80 & 78 & 73 & 97 & 113 & 101 & 100 & 72 & 85 \\
\hline $\bar{\chi}$ & 84 & 99 & 108 & 113 & 107 & 98 & 96 & 80 & 99 & 107 & 103 & 88 & 81 & 78 \\
\hline SEM & 7 & 8 & 8 & 9 & 11 & 5 & 6 & 3 & 3 & 6 & 4 & 4 & 2 & 3 \\
\hline
\end{tabular}

Plasma insulin, $\mu \mathrm{U} / \mathrm{ml}$

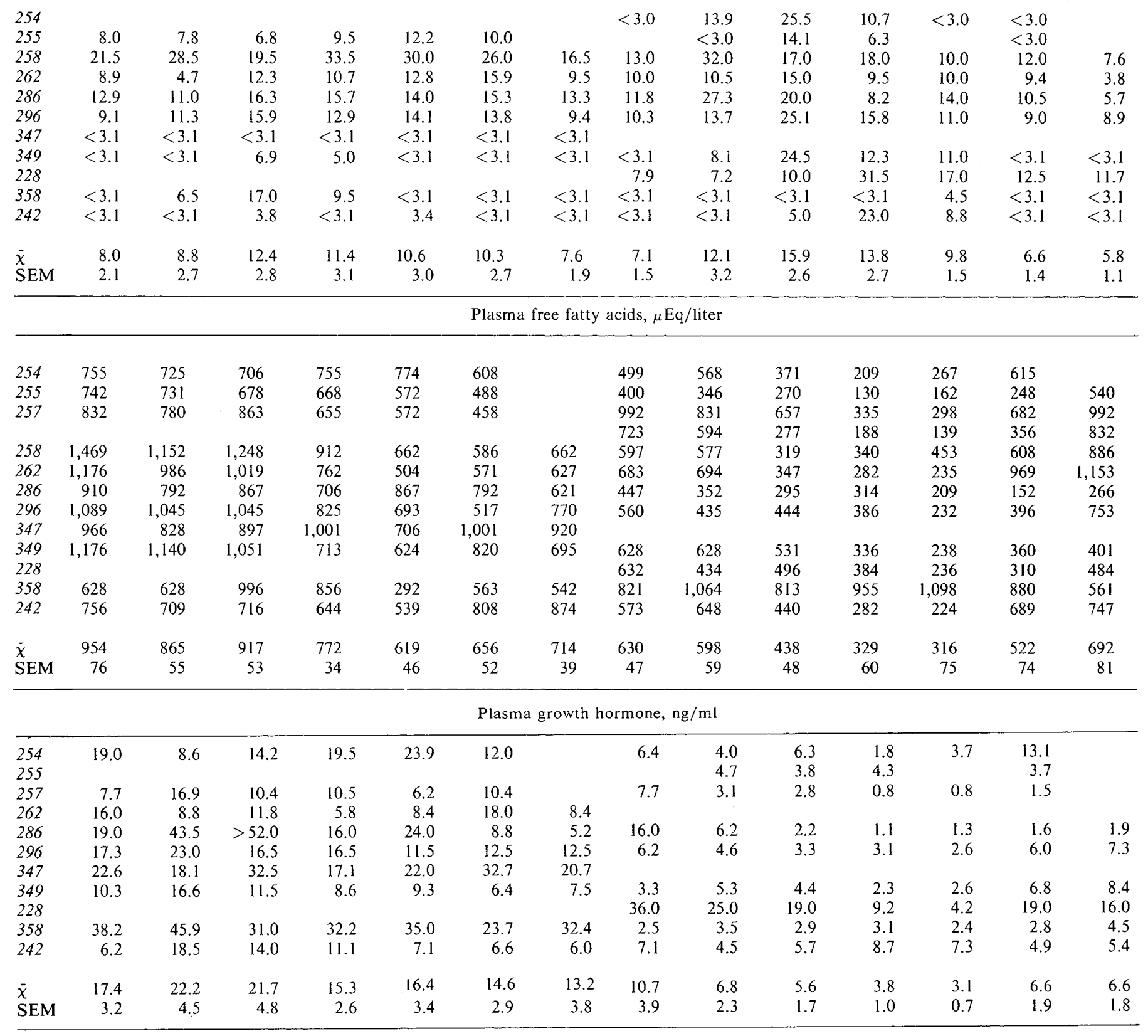



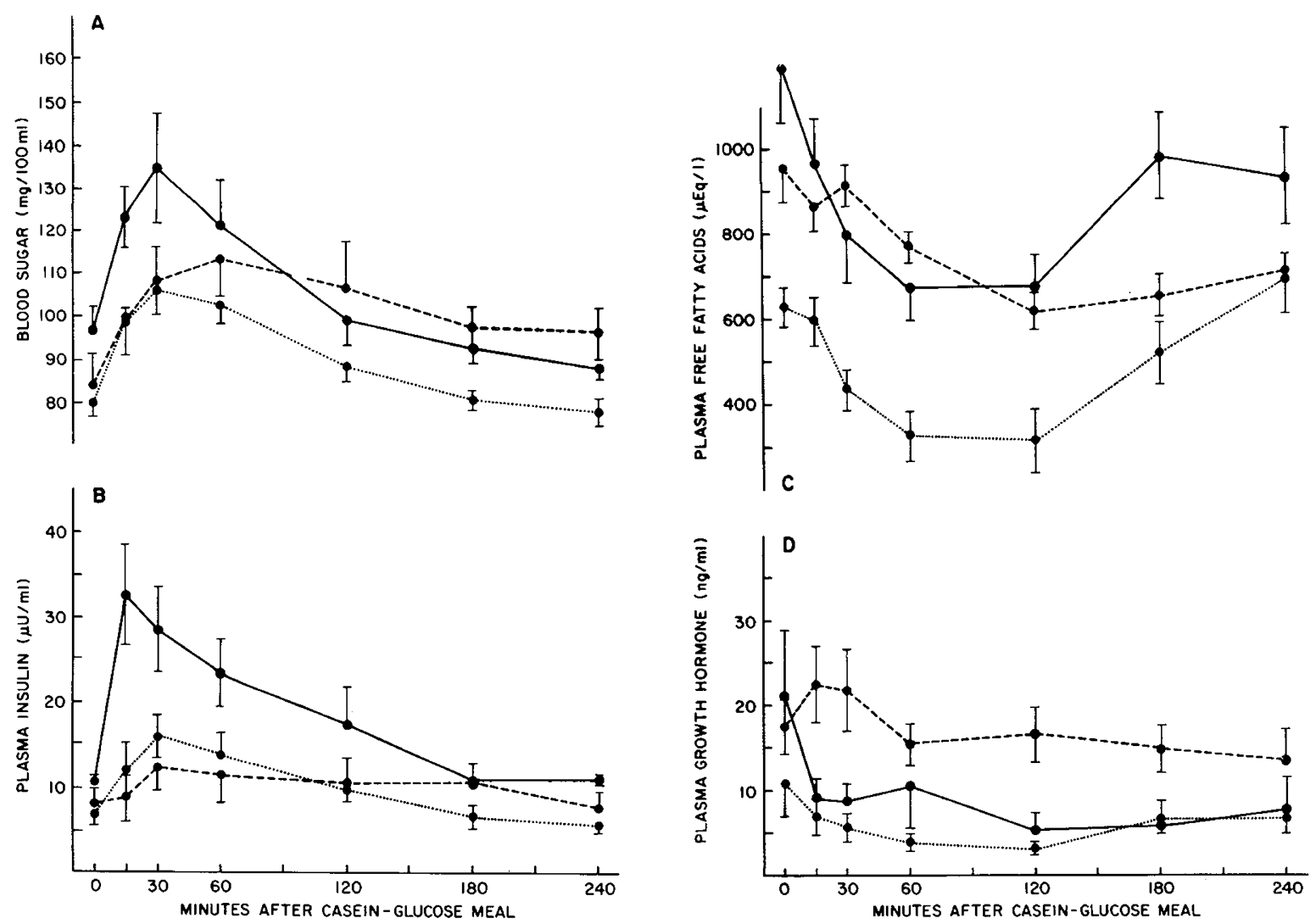

Fig. 3. Mean $( \pm \mathrm{SE})$ blood sugar $(A)$, plasma insulin $(B)$, free fatty acid $(C)$, and growth hormone $(D)$ responses of children with marasmic kwashiorkor to a casein-glucose meal on the day after admission (- comparable size (-). Results from group $\mathrm{C}$-3 only are used for normal values.

min, with only modest gradual falls subsequently. There was no relation apparent between $\mathrm{GH}$ levels or responsiveness and FFA rebounds, which were poor.

During rehabilitation, fasting BS was, with one exception, in the low normal range. Three demonstrated "flat" tolerances. Peak elevations in the remaining nine occurred at 30 or $60 \mathrm{~min}$, but were significantly lower than those of the control subjects at both times (Fig. $3 A$ ). Although at $120 \mathrm{~min}$ all had fallen below the peak, only two had reached the fasting level.

Fasting IRI after partial rehabilitation was unmeasurable in four children but the mean was not significantly lower than control or admission values. In eight children the postprandial IRI increase exceeded $13 \mu \mathrm{U}$, and in three it exceeded $20 \mu \mathrm{U}$. Peak levels exceeded $20 \mu \mathrm{U}$ in seven and $30 \mu \mathrm{U}$ in two children.

Fasting FFA were significantly $(P<0.02)$ lower than pretreatment or control levels (Fig. $3 C$ ). In all children they fell postprandially by more than $40 \%$, with the nadir at $120 \mathrm{~min}$ in 8 of the 12 . The $r$ value between lowest FFA and maximum IRI was not significant.

In only two children was fasting $\mathrm{GH}$ above $10 \mathrm{ng} / \mathrm{ml}$ and in both it was suppressed postprandially (Fig. $3 D$ and Table 4). In four studies there was no postprandial elevation. There was no clear relation between $\mathrm{GH}$ responses and FFA rebounds, or between fasting GH and FFA levels.

\section{DISCUSSION (TABLES 5-8)}

\section{NORMAL INFANTS}

Mean fasting capillary BS levels were generally higher than literature values. Some of the difference may be due to the use by others of venous blood or serum, and of different laboratory methods. Pickens et al. (37) used capillary blood and the SomogyiNelson method (35), as in the present report, in children between 1 and 13 years of age. Only our oldest group fell within this age category, and was found to have fasting BS levels within their normal range. It is possible that some of the higher fasting values. seen in this study were due to the stress of the previous blood-drawing.

Oral glucose tolerance was normal in 22 of our 24 healthy infants. The remaining two, being in the older age group, may have been more excited than the others. We found no significant age difference in tolerance, such as that reported by Loeb after intravenous loading (25).

Peak IRI response to the meal did not correlate well with peak BS, but in these studies glucose and protein were given, and both produce an insulin response (46). In Figure $4 A$ we have plotted the mean ratio of plasma IRI to the $\mathrm{BS}$ at each stated time for the three groups. It is suggestive of a greater and more sustained IRI response by the younger infants to a comparable BS elevation, possibly explaining the lower BS levels at $120 \mathrm{~min}$.

The more than $40 \%$ drop in postprandial plasma FFA seen in most healthy infants, and its temporal relation to peak BS and IRI, suggests that either or both inhibit FFA release from adipose tissue and muscle (43). The timing of rebounds in FFA was much more closely related to fall in BS and IRI than to GH responses.

Fasting GH levels were above the range reported for older children and adults but were promptly and effectively suppressed by the meal. Comparably elevated fasting levels have been reported in normal infants up to 10 days of age (18). In more than two-thirds of the normal infants in this study there were subsequent rises in $\mathrm{GH}$ which may represent responses to protein.

\section{MARASMUS}

The results from the malnourished infants who were subsequently shown to be severely infected should possibly be excluded from this analysis and report, and in fact they are not included in 

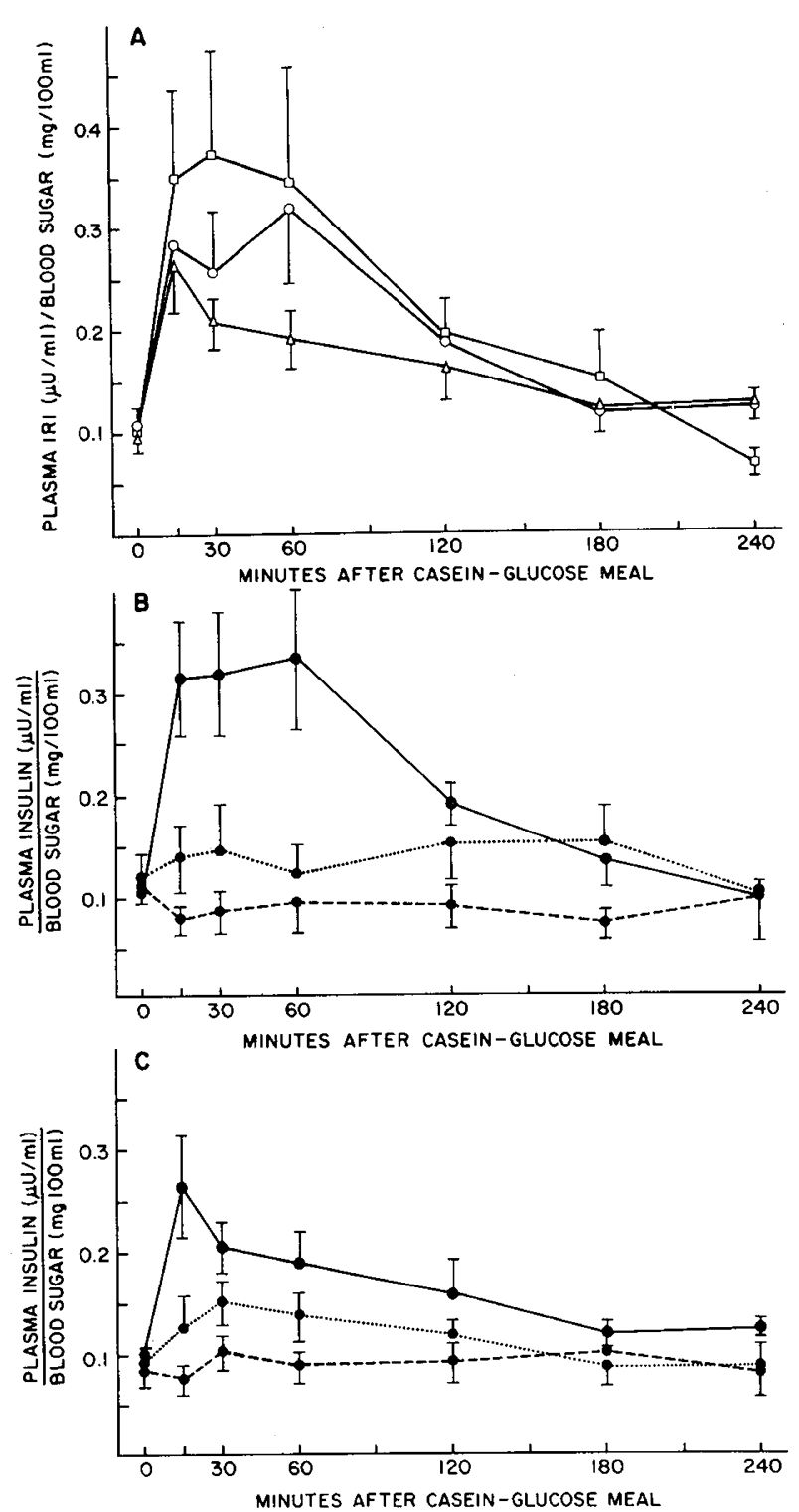

Fig. 4. Mean ( $t \mathrm{SE}$ ) ratio of plasma insulin to blood sugar before and after a casein-glucose meal. In $A$ open squares ( $\square$ ) correspond to youngest normal infants $(C-I)$, circles $(O)$ to intermediate $(C-2)$, and triangles $(\triangle)$ to oldest group $(C-3)$. Mean $( \pm \mathrm{SE})$ ratios of marasmic infants are compared with $C-1$ and $C-2$ combined in $B$ and of children with marasmic kwashiorkor to group $C$-3 in $C$. $\bullet-. \bullet$, admission values; $\bullet \cdots \bullet$, convalescence; - appropriate normal controls.

the paired statistical comparisons. To omit them altogether would imply that the other infants were not infected, which is most unlikely; severe malnutrition and severe infection are almost inseparable. Their inclusion in the group means helps to explain the variability in hormonal and metabolic responses found in our studies and in those of others, most of which make no mention of complicating infections.

On the day after admission most infants had fasting BS in the low range reported by others $(2,8,12,17,19,31,36,39)$ but two had levels of 124 and $137 \mathrm{mg} / 100 \mathrm{ml}$. The occurrence of similar levels with the same frequency in the healthy infants deprives this finding of special significance. It may well be due to the stress of the previous blood-drawing, as in the control subjects. After partial rehabilitation, fasting BS levels were normal in all cases.

The delay in reaching peak BS is suggestive of impaired glucose absorption, and was less evident after partial rehabilitation. The relatively low peak BS before treatment could have been the result of carbohydrate deprivation before admission, but similar findings were still present after partial rehabilitation, and were present in some healthy infants. Failure to return to the fasting level at 120 min may in at least one case have been due to delayed absorption, but in others it was probably due to impaired oral glucose tolerance, as found by others $(6,19)$. Marked improvement after partial rehabilitation has also been reported (6). More nearly normal tolerance to intravenous glucose has been found initially $(2$, $6)$, with occasional deterioration after partial rehabilitation $(6,31)$.

Fasting IRI levels below the sensitivity of the method, found in three marasmic infants, were not seen in normal infants, and are in general accord with those reported $(6,12,19,31,36)$. Very poor insulin responses to the meal, both in absolute terms and as a function of the BS elevation (Fig. $4 B$ ), have also been reported (6, $31,32,36)$. The partial responses seen in only two infants, and the generally modest BS elevations produced by the oral glucose load in our patients, suggest that the normal insulin responses to an intravenous load reported in one study (12) were probably due to a greater glycemic stimulus. Becker et al. (6) have suggested that an impaired gut $\beta$-cytotrophic mechanism might be partly responsible for the altered release mechanisms found after oral glucose loading early in treatment. After partial rehabilitation, glucose tolerance

Table 5. Blood sugar responses of healthy infants to casein-glucose meal

\begin{tabular}{|c|c|c|c|c|c|c|c|}
\hline \multirow[b]{2}{*}{ Case } & \multicolumn{7}{|c|}{ Blood sugar, $\mathrm{mg} / 100 \mathrm{ml}$} \\
\hline & $\begin{array}{c}0 \\
\min \end{array}$ & $\begin{array}{c}15 \\
\min \end{array}$ & $\begin{array}{c}30 \\
\min \end{array}$ & $\begin{array}{c}60 \\
\min \end{array}$ & $\begin{array}{l}120 \\
\min \end{array}$ & $\begin{array}{l}180 \\
\min \end{array}$ & $\begin{array}{l}240 \\
\min \end{array}$ \\
\hline \multicolumn{8}{|c|}{$\begin{array}{l}\text { Group C-1 (2.1- } \\
3.2 \text { months) }\end{array}$} \\
\hline 248 & 109 & 140 & 165 & 176 & 66 & 54 & \\
\hline 247 & 129 & & 188 & 223 & 114 & 105 & \\
\hline 236 & 135 & 172 & 138 & 128 & 104 & 96 & \\
\hline 231 & 101 & 136 & 112 & 91 & 74 & 91 & \\
\hline 276 & 115 & 177 & 200 & 102 & 105 & 72 & 78 \\
\hline 277 & 108 & 158 & 236 & 164 & 61 & 24 & 91 \\
\hline 304 & 97 & 103 & 159 & 154 & 126 & 79 & 88 \\
\hline 309 & 93 & 125 & 183 & 142 & 79 & 99 & 93 \\
\hline $\bar{\chi}$ & 110.9 & 144.4 & 172.6 & 147.5 & 91.1 & 77.5 & 87.5 \\
\hline$\widehat{S} E M$ & 5.3 & 10.0 & 13.5 & 14.9 & 8.5 & 9.6 & 3.3 \\
\hline \multicolumn{8}{|c|}{$\begin{array}{c}\text { Group C-2 (4.5- } \\
10.6 \text { months) }\end{array}$} \\
\hline 235 & 83 & 123 & 131 & 62 & 69 & 72 & \\
\hline 239 & 78 & 92 & 103 & 81 & 80 & 78 & \\
\hline 245 & 126 & 173 & 195 & 128 & 73 & 86 & \\
\hline 248 & 97 & 119 & 152 & 144 & 99 & 95 & 83 \\
\hline 247 & 102 & 139 & 182 & 193 & 93 & 74 & 69 \\
\hline 245 & 132 & 166 & & 186 & 166 & 117 & 95 \\
\hline 277 & 100 & 138 & 162 & 124 & 85 & 73 & 98 \\
\hline 273 & 100 & 120 & 118 & 98 & 93 & 83 & 80 \\
\hline $\bar{\chi}$ & 102.3 & 133.8 & 149.0 & 127.0 & 94.8 & 84.8 & 85.0 \\
\hline SEM & 6.6 & 9.3 & 12.7 & 16.5 & 10.8 & 5.4 & 5.3 \\
\hline \multicolumn{8}{|c|}{$\begin{array}{c}\text { Group C-3 (12.5- } \\
18.5 \text { months) }\end{array}$} \\
\hline 199 & 100 & 108 & 167 & 130 & 124 & 81 & \\
\hline 193 & 122 & 160 & 205 & 185 & 125 & 113 & \\
\hline 193 & 92 & 124 & 136 & 139 & 84 & 99 & \\
\hline 190 & 68 & 93 & 94 & 94 & 94 & 88 & \\
\hline 231 & 86 & 134 & 101 & 93 & 81 & 83 & 85 \\
\hline 236 & 109 & 120 & 124 & 119 & 95 & 95 & 95 \\
\hline 235 & 96 & 136 & 133 & 104 & 92 & 94 & 85 \\
\hline 239 & 99 & 111 & 121 & 109 & 101 & 92 & 89 \\
\hline $\bar{\chi}$ & 96.5 & 123.8 & 135.1 & 121.6 & 99.5 & 93.1 & 88.5 \\
\hline SEM & 5.6 & 7.2 & 12.7 & 10.7 & 5.9 & 3.6 & 2.4 \\
\hline
\end{tabular}


Table 6. Immunoreactive insulin responses of healthy infants to casein-glucose meal

\begin{tabular}{|c|c|c|c|c|c|c|c|}
\hline \multirow[b]{2}{*}{ Case } & \multicolumn{7}{|c|}{ Plasma insulin, $\mu \mathrm{U} / \mathrm{ml}$} \\
\hline & $\begin{array}{c}0 \\
\min \end{array}$ & $\begin{array}{l}15 \\
\min \end{array}$ & $\begin{array}{l}30 \\
\min \end{array}$ & $\begin{array}{l}60 \\
\min \end{array}$ & $\begin{array}{l}120 \\
\min \end{array}$ & $\begin{array}{l}180 \\
\min \end{array}$ & $\begin{array}{l}240 \\
\min \end{array}$ \\
\hline \multicolumn{8}{|c|}{$\begin{array}{c}\text { Group C-I (2.1- } \\
3.2 \text { months) }\end{array}$} \\
\hline 248 & 7.2 & 16.8 & 9.7 & 35.8 & 9.0 & $<3.0$ & \\
\hline 247 & 10.1 & 8.1 & 15.3 & 14.5 & 17.4 & 14.6 & \\
\hline 236 & 19.0 & 39.3 & 37.5 & 11.9 & 17.6 & 18.0 & \\
\hline 231 & 12.9 & 88.0 & 64.5 & 60.0 & 18.8 & 10.2 & \\
\hline 276 & 12.3 & 70.0 & 93.5 & 28.3 & 29.5 & 11.3 & 6.3 \\
\hline 277 & 13.8 & 101.0 & 215.0 & 163.0 & 22.4 & 11.0 & 8.9 \\
\hline 304 & 6.4 & 9.6 & 24.8 & 22.0 & 13.5 & 6.0 & $<6.0$ \\
\hline 309 & 3.7 & 41.0 & 84.0 & 48.0 & 6.8 & $<3.1$ & $<3.1$ \\
\hline $\bar{\chi}$ & 10.7 & 46.7 & 68.0 & 47.9 & 16.9 & 9.5 & 5.8 \\
\hline SEM & 1.7 & 12.7 & 23.7 & 17.4 & 2.6 & 2.0 & 1.2 \\
\hline \multicolumn{8}{|c|}{$\begin{array}{c}\text { Group C-2 (4.5- } \\
\quad 10.6 \text { months) }\end{array}$} \\
\hline 235 & 3.5 & 7.2 & 22.9 & 11.8 & 11.2 & 12.0 & \\
\hline 239 & 6.4 & 28.0 & 37.5 & 36.0 & 9.2 & 8.5 & \\
\hline 245 & 12.9 & 59.0 & 93.0 & 79.0 & 20.0 & 8.3 & \\
\hline 248 & 9.9 & 12.2 & 14.3 & 11.4 & 9.5 & 7.7 & 8.7 \\
\hline 247 & 10.3 & 12.9 & 9.6 & 19.2 & 11.1 & 5.0 & 6.2 \\
\hline 245 & 13.7 & 66.5 & & 62.0 & 38.3 & 9.7 & 9.9 \\
\hline 277 & 11.0 & 35.0 & 49.5 & 72.0 & 16.2 & 15.5 & 15.0 \\
\hline 273 & 18.9 & 88.0 & 40.0 & 20.5 & 28.8 & & 12.7 \\
\hline $\bar{\chi}$ & 10.8 & 38.6 & 38.1 & 39.0 & 18.0 & 9.5 & 10.5 \\
\hline SEM & 1.6 & 10.4 & 10.6 & 9.9 & 3.7 & 1.3 & 1.5 \\
\hline \multicolumn{8}{|c|}{$\begin{array}{l}\text { Group C-3 (12.5- } \\
18.5 \text { months) }\end{array}$} \\
\hline 199 & 12.4 & 56.5 & 58.5 & 39.5 & 39.0 & 11.9 & \\
\hline 193 & 15.9 & 39.0 & 39.0 & 30.3 & 35.5 & 11.9 & \\
\hline 193 & $<3.0$ & 21.0 & 28.8 & 30.0 & 7.9 & 6.3 & \\
\hline 190 & 12.5 & 20.5 & 24.0 & 27.0 & 11.5 & 6.6 & \\
\hline 231 & 11.0 & 60.0 & 15.0 & 14.9 & 9.5 & 15.0 & 12.0 \\
\hline 236 & 13.5 & 25.0 & 24.5 & 26.5 & 17.0 & 13.8 & 9.5 \\
\hline 235 & 6.2 & 21.0 & 13.7 & 5.9 & 5.6 & 10.8 & 11.4 \\
\hline 239 & 8.2 & 17.3 & 23.3 & 12.3 & 12.0 & 12.1 & 11.4 \\
\hline $\bar{\chi}$ & 10.2 & 32.5 & 28.4 & 23.3 & 17.3 & 11.1 & 11.1 \\
\hline SEM & 1.6 & 6.1 & 5.1 & 3.9 & 4.5 & 1.1 & 0.5 \\
\hline
\end{tabular}

was improved (Fig. 2); before treatment the 120-min BS had been above fasting in six of nine infants; it was now above fasting in only one of seven. IRI responses, both in absolute terms and as a function of BS elevation (Fig. $4 B$ ), were still impaired. Although the poor responsiveness of at least two infants may have been due to the meager glycemic stimulus, this was not the case for most of the infants, whose normal glucose tolerance despite poor insulin release suggests enhanced sensitivity to insulin. All were still severely underweight for height at the time of the second study; Baird (3) has suggested that very small amounts of circulating insulin are required to maintain normal BS and FFA levels in thin individuals. The less striking improvement in the IRI responses of our patients than in those of Becker et al. (6) may be due to differences in dietary management or the degree of recovery in weight at the time of the second study.

The fasting FFA were much higher than those of normal infants of comparable age or size, or those of the same infants after partial rehabilitation. This is compatible with the reports of others in marasmus $(21,24,31)$ and in hypotrophic newborn infants $(1,29)$. The more normal fasting FFA found by some investigators $(16,17)$ may have been due to differences in age or in dietary management before study; high carbohydrate feedings usually suppress elevated
FFA (32). In the marasmic infants suppression was as profound as in the normal or partially rehabilitated. That some demonstrated considerable suppression, without measurable insulin responses, is in accord with the concept of a glucose-FFA cycle independent of insulin (43). The even more profound suppression in those with measurable IRI responses is in accord with the demonstration by Zierler and Rabinowitz (48) of the effect of very small concentrations of insulin on FFA release.

A positive effect of $\mathrm{GH}$ administration on the growth and nitrogen retention of marasmic infants who had not responded satisfactorily to presumably adequate diets suggested that they were deficient in GH (34); low fasting GH levels and a poor response to arginine supported this impression (4). Godard and Zahnd (12) found normal or slightly elevated fasting $\mathrm{GH}$ in six marasmic infants, five responding to intravenous glucose. In a previous study they had found normal, low, or moderately elevated levels; some had no response to insulin-induced hypoglycemia; others did show apparently significant elevations (11). These studies $(4,11,12,34)$ were of infants who had been treated for days or weeks; they are not representative of the initial metabolic and hormonal status. A further report described moderately elevated $\mathrm{GH}$, particularly in

Table 7. Plasma free fatty acid responses of healthy infants to casein-glucose meal

\begin{tabular}{|c|c|c|c|c|c|c|c|}
\hline \multirow[b]{2}{*}{ Case } & \multicolumn{7}{|c|}{ Plasma free fatty acids, $\mu \mathrm{Eq} /$ liter } \\
\hline & $\begin{array}{c}0 \\
\min \end{array}$ & $\begin{array}{c}15 \\
\min \end{array}$ & $\begin{array}{l}30 \\
\min \end{array}$ & $\begin{array}{c}60 \\
\min \end{array}$ & $\begin{array}{l}120 \\
\min \end{array}$ & $\begin{array}{l}180 \\
\min \end{array}$ & $\begin{array}{l}240 \\
\min \end{array}$ \\
\hline \multicolumn{8}{|c|}{$\begin{array}{l}\text { Group } C-1(2.1- \\
3.2 \text { months) }\end{array}$} \\
\hline 248 & 990 & 860 & 750 & 540 & 590 & 910 & \\
\hline 247 & 1113 & 1049 & 995 & 546 & 556 & 792 & \\
\hline 236 & 606 & 568 & 346 & 366 & 471 & 770 & \\
\hline 231 & 771 & 702 & 311 & 299 & 380 & 725 & \\
\hline 276 & 806 & 730 & 371 & 256 & 333 & 576 & 602 \\
\hline 277 & 436 & 363 & 254 & 254 & 363 & 714 & 944 \\
\hline 304 & 674 & 547 & 594 & 434 & 322 & 330 & 412 \\
\hline 309 & 919 & 767 & 655 & 336 & 288 & 615 & 687 \\
\hline $\bar{\chi}$ & 789 & 698 & 534 & 379 & 413 & 679 & 661 \\
\hline SEM & 77 & 74 & 91 & 41 & 40 & 62 & 110 \\
\hline \multicolumn{8}{|c|}{$\begin{array}{c}\text { Group C-2 (4.5- } \\
10.6 \text { months) }\end{array}$} \\
\hline 235 & 1,039 & 1,155 & 986 & 678 & 922 & 1,155 & \\
\hline 239 & 1,336 & 1,008 & 794 & 428 & 718 & 1,021 & \\
\hline 245 & 1,144 & 936 & 510 & 385 & 562 & 718 & \\
\hline 248 & 901 & 778 & 785 & 362 & 477 & 547 & 986 \\
\hline 247 & 964 & 916 & 798 & 514 & 419 & 679 & 1,556 \\
\hline 245 & 1,209 & 1,352 & & 798 & 983 & 1,008 & 1,126 \\
\hline 277 & 960 & 903 & 580 & 418 & 390 & 741 & 1,074 \\
\hline 273 & 845 & 962 & 715 & 689 & 767 & 741 & 1,001 \\
\hline $\bar{\chi}$ & 1,050 & 1,001 & 738 & 534 & 655 & 826 & 1,149 \\
\hline SEM & 59 & 62 & 59 & 58 & 80 & 74 & 105 \\
\hline \multicolumn{8}{|c|}{$\begin{array}{c}\text { Group C-3 (12.5- } \\
18.5 \text { months) }\end{array}$} \\
\hline 199 & 1,530 & 1,063 & 660 & 451 & 451 & 1,224 & \\
\hline 193 & 954 & 890 & 620 & 652 & 493 & 557 & \\
\hline 193 & 1,840 & 1,560 & 1,540 & 980 & 900 & 1,220 & \\
\hline 190 & 1,320 & 1,160 & 1,020 & 940 & 1,020 & 980 & \\
\hline 231 & 1,243 & 730 & 512 & 436 & 458 & 676 & 763 \\
\hline 236 & 810 & 666 & 566 & 466 & 722 & 1,410 & 1,265 \\
\hline 235 & 731 & 773 & 689 & 655 & 764 & 865 & 832 \\
\hline 239 & 1,112 & 916 & 810 & 823 & 596 & 932 & 874 \\
\hline $\bar{\chi}$ & 1,193 & 970 & 802 & 675 & 676 & 983 & 934 \\
\hline SEM & 132 & 103 & 119 & 77 & 75 & 102 & 113 \\
\hline
\end{tabular}


Table 8. Plasma growth hormone responses of healthy infants to casein-glucose meal

\begin{tabular}{|c|c|c|c|c|c|c|c|}
\hline \multirow[b]{2}{*}{ Case } & \multicolumn{7}{|c|}{ Plasma growth hormone, $\mathrm{ng} / \mathrm{ml}$} \\
\hline & $\begin{array}{c}0 \\
\min \end{array}$ & $\begin{array}{c}15 \\
\min \end{array}$ & $\begin{array}{c}30 \\
\min \end{array}$ & $\begin{array}{c}60 \\
\min \end{array}$ & $\begin{array}{l}120 \\
\min \end{array}$ & $\begin{array}{l}180 \\
\min \end{array}$ & $\begin{array}{l}240 \\
\min \end{array}$ \\
\hline \multicolumn{8}{|c|}{$\begin{array}{l}\text { Group } C-1(2.1- \\
\quad 3.2 \text { months) }\end{array}$} \\
\hline 248 & 33.0 & 16.0 & 14.0 & 15.0 & 12.0 & 4.5 & \\
\hline 247 & 27.0 & 21.0 & 13.0 & 24.0 & 40.0 & 21.0 & \\
\hline 236 & 57.0 & 30.0 & 30.0 & 21.0 & 17.0 & 8.0 & \\
\hline 231 & 45.0 & 17.0 & 13.0 & 12.5 & 8.2 & $>60.0$ & \\
\hline 276 & 56.0 & 23.0 & 15.5 & 27.0 & 20.0 & 10.5 & 16.0 \\
\hline 277 & 38.0 & 19.0 & 16.0 & 16.0 & 11.0 & 4.0 & 23.0 \\
\hline 304 & 34.0 & 18.0 & 16.0 & 20.0 & 17.0 & 34.0 & 29.0 \\
\hline 309 & 18.0 & 6.5 & 9.4 & 9.4 & 4.3 & 3.1 & 1.6 \\
\hline $\bar{\chi}$ & 38.5 & 18.8 & 15.9 & 18.1 & 16.2 & 18.8 & 17.4 \\
\hline SEM & 4.8 & 2.4 & 2.2 & 2.1 & 3.8 & 7.6 & 5.9 \\
\hline \multicolumn{8}{|c|}{$\begin{array}{c}\text { Group C-2 (4.5- } \\
10.6 \text { months) }\end{array}$} \\
\hline 235 & 28.0 & 12.0 & 5.4 & 21.0 & 5.8 & 3.3 & \\
\hline 239 & 24.0 & 13.0 & 7.0 & 6.6 & 23.0 & 11.0 & \\
\hline 245 & 43.0 & 24.0 & 10.0 & 4.3 & 2.1 & 2.5 & \\
\hline 248 & 14.5 & 11.5 & 14.0 & 10.0 & 60.0 & 23.0 & 5.2 \\
\hline 247 & 11.0 & 5.4 & 5.4 & 4.3 & 23.0 & 4.3 & 2.0 \\
\hline 245 & 50.0 & 21.0 & & 16.0 & 5.8 & 2.4 & 3.3 \\
\hline 277 & 14.0 & 8.6 & 4.1 & 4.6 & 5.8 & 9.4 & 20.0 \\
\hline 273 & 26.0 & 11.0 & 7.2 & 10.0 & 6.8 & & 6.2 \\
\hline $\bar{x}$ & 26.3 & 13.3 & 7.6 & 9.6 & 16.5 & 8.0 & 7.3 \\
\hline SEM & 4.9 & 2.2 & 1.3 & 2.3 & 6.8 & 2.8 & 3.3 \\
\hline \multicolumn{8}{|c|}{$\begin{array}{l}\text { Group C-3 (12.5- } \\
18.5 \text { months) }\end{array}$} \\
\hline 199 & $>50.0$ & 3.6 & 4.5 & 9.0 & 3.3 & 10.3 & \\
\hline 193 & 2.4 & 2.7 & 5.6 & 6.2 & 2.3 & 2.6 & \\
\hline 193 & 3.1 & 12.5 & 19.0 & 11.0 & 3.2 & 3.0 & \\
\hline 190 & 9.0 & 8.5 & 11.0 & 3.2 & 4.5 & 6.5 & \\
\hline 231 & 4.5 & 4.0 & 2.3 & 1.5 & 1.3 & 2.6 & $<1.0$ \\
\hline 236 & 18.0 & 4.2 & 2.9 & 1.8 & $<1.0$ & 1.8 & $<1.0$ \\
\hline 235 & 19.0 & 11.3 & 6.8 & 4.6 & 4.7 & 6.1 & 14.3 \\
\hline 239 & $>50.0$ & 23.0 & 14.5 & 44.5 & 19.0 & 10.3 & 14.0 \\
\hline $\bar{\chi}$ & 20.8 & 8.7 & 8.3 & 10.2 & 4.9 & 5.4 & 7.3 \\
\hline SEM & 7.8 & 2.4 & 2.1 & 5.0 & 2.1 & 1.2 & 3.9 \\
\hline
\end{tabular}

patients with low serum albumin, but did not specify the timing of the studies (44). Still another found relatively normal levels in six cases, only two being moderately elevated (42). Increased GH has been reported in anorexia nervosa $(23,28)$, cystic fibrosis $(15,33)$, marasmus due to cerebral disease (21), and the maternal deprivation syndrome (22).

Pimstone et al. (39) studied 20 cases of marasmus, 10 to 51 months of age, on the day after admission before dietary therapy. All but three had "elevated" fasting GH levels, with a mean of 26.0 $\pm 3.3(\mathrm{SEM}) \mathrm{ng} / \mathrm{ml}$. The fact that all but two had serum albumin levels below $3.0 \mathrm{~g} / 100 \mathrm{ml}$, plus their generally more advanced age, makes them have much in common with most cases of MK. In four cases studied before therapy, we previously found two with "high" fasting levels and two with responses to arginine (14). The evidence suggests that in untreated marasmus, plasma GH is already elevated, or responds appropriately to different stimuli. During the first few weeks of dietary therapy, the responsiveness of GH may be blunted $(4,14,34)$.

When compared with those of healthy infants matched for age or size, the fasting $\mathrm{GH}$ levels found in untreated marasmus in the present study and others $(39,44)$ must be considered normal, not "high." The very poor or delayed suppression is abnormal; this may be due to a poor or delayed glycemic stimulus, but this was not true in most of our cases, or in infants receiving intravenous glucose $(31,38,39)$. In at least half of our patients there was some evidence of a subsequent $\mathrm{GH}$ response, possibly to the protein component of the meal. After partial rehabilitation, fasting GH levels were moderately lower, but not significantly so. This is compatible with the reports of others who studied partially treated infants $(4,11,12)$. The finding of a $\mathrm{GH}$ response to the protein-glucose meal in some, but not all partially rehabilitated infants is in accord with data of Godard and Zahnd $(11,12)$, but not that of Beas et al. (4). In a previous limited study we found that some partially recovered infants responded to arginine whereas others did not (14).

Our findings in fasting, untreated marasmic infants can be summarized as follows: normal or low BS, normal or low IRI, markedly elevated FFA, and normal GH. Responses to a proteinglucose meal were characterized by some delay in BS elevation (delayed absorption?), mildly impaired glucose tolerance, and very poor or unmeasurable insulin release. Modest IRI and BS elevations, when present, were adequate to block FFA release from muscle and adipose tissues, suggesting normal or enhanced insulin sensitivity. GH levels were poorly suppressed by glucose, but some of the infants probably responded with further $\mathrm{GH}$ secretion to the protein in the test meal.

After 23 to 78 days of dietary treatment, when all had begun to gain weight, there was a normalization of fasting FFA. Insulin release, although increased, was still much below normal, but adequate for normal glucose utilization and blockage of FFA release.

Findings in marasmic infants, particularly before treatment, are more like those of normal or hypotrophic newborn infants $(3,29)$ than those of age or size controls. Merimee et al. (30) have suggested that the BS-insulin-FFA mechanism is the major control for regulating substrate availability during starvation, operating independently of $\mathrm{GH}$ if necessary; prior or concomitant exposure to $\mathrm{GH}$ affects the homeostatic setting. The close temporal relations between BS, IRI, and FFA levels in our patients, seemingly independent of changes in $\mathrm{GH}$ levels, are in accord with this scheme. The major hormonal adaptation in marasmus appears to be a markedly decreased insulin release. The persistence of this adaptive change is probably responsible for the poor accretions of lean body mass, particularly muscle protein, in convalescent malnourished infants who are laying down body fat and gaining weight (14).

Although significant hypokalemia was not present in our patients at the time of study (9), K deficiency may have existed and caused some impairment of insulin release, as postulated by Mann et al. (27). Its persistence after partial rehabilitation, when there was no $\mathrm{K}$ deficiency, does not favor this as a major factor. More likely, the nearly total disappearance of body fat stores renders these infants quite insulin sensitive and the very modest amounts released are probably appropriate to sustain essential metabolic processes.

The alterations in energy substrate levels and responses and in the major hormones involved all seem to be part of a convenient adaptation for survival in the face of chronic starvation. Severe infection, when superimposed, makes new demands which exaggerate these responses, and may find the organism incapable of meeting them.

\section{MARASMIC KWASHIORKOR}

Mean fasting BS of children with MK was not significantly different from that of normal or marasmic infants. Peak postprandial elevations were delayed more often until 60 , ore even $120 \mathrm{~min}$, suggesting that glucose absorption was more impaired. After partial rehabilitation there was still some abnormality, particularly in the form of minimal postprandial peaks.

Fasting and peak IRI levels were significantly correlated with BS values, but the IRI/BS ratio (Fig. 4C) was consistently low, as 
found by others $(6,8,26,31,32)$. The more severe hypokalemia of MK (9) makes potassium deficiency appear to be a plausible cause of impaired insulin release in this group of patients. In three children there was a delayed or sustained IRI response, possibly related to delayed glucose absorption or to the protein in the meal. After partial rehabilitation, when there was no evidence of $\mathrm{K}$ deficiency, fasting levels were still low, but responses to the meal, although moderate, were improved and more appropriate in their timing. In some patients, poor insulin responses have been found to persist for days or even months after the start of rehabilitation (12, $19,31,41)$, whereas in others normalization has been reported as occurring in a few weeks $(2,6,12,41)$. In healthy children who had been malnourished years earlier, normal responses were found $(6$, 20).

The normal fasting FFA of MK in our study are not in accord with others $(24,31)$. Our oldest control group was considerably younger than the patients with MK; more appropriate control subjects might have had lower levels. Also, because of the more precarious metabolic status of MK, we gave one or two proteincarbohydrate feedings on the day of admission; this may have lowered FFA. The much delayed suppression after the meal can be attributed to delayed and minimal BS and IRI elevations. During rehabilitation postprandial suppression was prompt and efficient, and closely related to peak BS and IRI, indicative of normalization of the BS-IRI-FFA mechanism (30).

The earliest determinations of fasting $\mathrm{GH}$ in untreated kwashiorkor found it to be consistently elevated (40); this has been confirmed $(4,12,14,26,31,32,39)$. Elevated levels were not suppressed by induced hyperglycemia $(31,38,39)$ and were not further raised by intravenous arginine $(4,14)$, but dropped promptly after meals containing protein $(39,40)$ or a mixture of essential amino acids (32). Significant inverse correlations between plasma $\mathrm{GH}$ and serum albumin levels $(7,26)$ suggest a causal relationship, but artificially raising serum albumin levels did not have a predictable effect on $\mathrm{GH}$ levels $(5,7)$, suggesting that they are independent manifestations of protein deficiency.

Although mean GH of MK in the present study was not higher than that of the control subjects, this may be the result of the protein-containing meals of the previous day and of the lack of proper age controls. Whereas all healthy infants under 1 year of age had fasting $\mathrm{GH}$ levels above $10 \mathrm{ng} / \mathrm{ml}$, only four of the eight between 12.5 and 18.5 months did so, suggesting that this would have been even less frequent at 2 to 3 years of age. The two youngest children with MK, ages 15.7 and 15.9 months, had the highest fasting GH levels, 38.2 and $22.6 \mathrm{ng} / \mathrm{ml}$. The failure of the test meal to suppress $\mathrm{GH}$ is in accord with the experience of others $(31,38,39)$. After partial rehabilitation, six of eight had fasting levels below $10 \mathrm{ng} / \mathrm{ml}$, probably normal for their age. Only two of nine children had neither an elevated fasting level nor a significant postprandial elevation.

The findings in fasting, minimally treated children with MK can be summarized as follows: normal or low BS, normal or low IRI, normal FFA, and probably elevated GH. Responses to a proteinglucose meal were characterized by a presumed delay in glucose absorption and very poor or unmeasurable insulin release. There was less evidence of sensitivity to insulin, as evidenced by delayed or absent FFA suppression, than in marasmus, with hypokalemia (9) and less depleted body fat stores (13) as possible contributing factors. The poor FFA and GH suppressions may have been to some extent the result of delayed or poor blood glucose elevations.

After 23 to 74 days of treatment, when all were free of edema, had normal or nearly normal serum albumin, had no evidence of $K$ deficiency, and were gaining weight, they had normal fasting BS and $\mathrm{GH}$, but FFA levels were low, and fasting IRI was still normal or low. There was improved but still delayed BS disappearance, improved IRI responses, and more normal GH responses to a protein-glucose meal.

\section{SUMMARY}

Fasting marasmic infants have normal or low BS, normal or low IRI, markedly elevated FFA, and normal GH levels. Rises in blood sugar after a protein-glucose meal are often delayed or poor, and disappearance is moderately delayed; insulin responses are very poor, but FFA release is adequately blocked; GH secretion, instead of being suppressed, may be further stimulated. During rehabilitation, poor insulin responses persist but the abnormalities in glucose utilization and fasting FFA levels are corrected.

In marasmic kwashiorkor the findings in the fasting state are similar, but FFA levels are much less elevated. Blood sugar elevation and its disappearance are significantly impaired, as are insulin responses, blockage of FFA release, and GH suppression after the test meal. During rehabilitation considerable recovery was evident but insulin responsiveness was not normalized.

\section{REFERENCES AND NOTES}

1. Anagnostakis, D. E., and Lardinois, R.: Urinary catecholamine excretion and plasma NEFA concentration in small-for-date infants. Pediatrics, 47: 1000 (1971).

2. Baig, H. A., and Edozien, J. C.: Carbohydrate metabolism in kwashiorkor. Lancet, ii: 662 (1965).

3. Baird, J. D.: Short-term hormonal responses to oral glucose in normal and abnormal energy metabolism. Proc. Nutr. Soc., 30: 26 (1971).

4. Beas, F., Contreras, I., Maccioni, A., and Arenas, S.: Growth hormone in infant malnutrition: The arginine test in marasmus and kwashiorkor. Brit. J. Nutr., 26: 169 (1971).

5. Becker, D. J., Pimstone, B. L., and Hansen, J. D. L.: The relation between insulin secretion, glucose tolerance, growth hormone, and serum proteins in proteincalorie malnutrition. Pediat. Res., 9: 35 (1975).

6. Becker, D. J., Pimstone, B. L., Hansen, J. D. L., and Hendricks, S.: Insulin secretion in protein-calorie malnutrition. 1. Quantitative abnormalities and response to treatment. Diabetes, 20: 542 (1971).

7. Becker, D. J., Pimstone, B. L., Hansen, J. D. L., and Hendricks, S.: Serum albumin and growth hormone relationships in kwashiorkor and the nephrotic syndrome. J. Lab. Clin. Med., 78: 865 (1971).

8. Becker, D. J., Pimstone, B. L., Hansen, J. D. L., MacHutchon, B., and Drysdale, A.: Patterns of insulin response to glucose in protein-calorie malnutrition. Amer. J. Clin. Nutr., 25: 499 (1972).

9. Beitins, I. Z., Graham, G. G., Kowarski, A., and Migeon, C. J.: Adrenal function in normal infants and in marasmus and kwashiorkor: Plasma aldosterone concentration and aldosterone secretion rate. J. Pediat., 84: 444 (1974).

10. Dole, V. P., and Meinertz, H.: Microdetermination of long-chain fatty acids in plasma and tissues. J. Biol. Chem., 235: 2595 (1960).

11. Godard, C., and Zahnd, G. R.: Growth hormone and insulin in severe infantile malnutrition. I. Plasma growth hormone response to hypoglycemia. Helv. Paediat. Acta, 26: 266 (1971).

12. Godard, C., and Zahnd, G. R.: Growth hormone and insulin in severe infantile malnutrition. II. Plasma insulin and growth hormone during intravenous glucose tolerance test. Helv. Paediat. Acta, 26: 276 (1971).

13. Graham, G. G., Baertl, J. M., Claeyssen, G., Suskind, R., Greenberg, A. H., Thompson, R. G., and Blizzard, R. M.: Thyroid hormonal studies in normal and severely malnourished infants and small children. J. Pediat., 83: 321 (1973).

14. Graham, G. G., Cordano, A., Blizzard, R. M., and Cheek, D. B.: Infantile malnutrition: changes in body composition during rehabilitation. Pediat. Res., 3: 579 (1969).

15. Green, O. C., Fefferman, R., and Nair, S.: Plasma growth hormone levels in children with cystic fibrosis and short stature: Unresponsiveness to hypoglycemia. J. Clin. Endocrinol., 27: 1059 (1967).

16. Gürson, C. T., Kurdoglu, G., and Saner, G.: Serum total lipids and lipid fractions in marasmus. Nutr. Metabol., 15: 181 (1973).

17. Hadden, D. R., and Rutishauser, I. H. E.: Effect of human growth hormone in kwashiorkor and marasmus. Arch. Dis. Childhood, 42: 29 (1967).

18. Humbert, J. R., and Gotlin, R. W.: Growth hormone levels in normoglycemic and hypoglycemic infants born small for gestational age. Pediatrics, 48: 190 (1971).

19. James, W. P. T., and Coore, H. G.: Persistent impairment of insulin secretion and glucose tolerance after malnutrition. Amer. J. Clin. Nutr., 23: 386 (1970).

20. Kajubi, S. K.: The endocrine pancreas after kwashiorkor. Amer. J. Clin. Nutr., 25: $1140(1972)$

21. Kerpel-Fronius, E., Gacs, G., and Hervei, C.: Growth hormone in marasmus due to cerebral disease. Amer. J. Dis. Child., 126: 303 (1973).

22. Krieger, I., and Mellinger, R. C.: Pituitary function in the deprivation syndrome. J. Pediatr., 79: 216 (1971).

23. Landon, J., Greenwood, F. C., Stamp, T. C. B., and Wynn, V.: The plasma sugar, free fatty acid, cortisol, and growth hormone response to insulin, and the comparison of this procedure with other tests of pituitary and adrenal function. II. In patients with hypothalamic or pituitary dysfunction or anorexia nervosa. J. Clin. Invest., 45: 437 (1966).

24. Lewis, B., Hansen, J. D. L., Wittman, W., Krut, L. H., and Stewart, F.: Plasma free fatty acids in kwashiorkor and the pathogenesis of the fatty liver. Amer. J. Clin. Nutr., I5: 161 (1964).

25. Loeb, H.: Variations in glucose tolerance during infancy and childhood. J. Pediat., 68: 237 (1966).

26. Lunn, P. G., Whitehead, R. G., Hay, R. W., and Barker, B. A.: Progressive changes in serum cortisol, insulin and growth hormone concentrations and their relationship to the distorted amino acid pattern during the development of 
kwashiorkor. Brit. J. Nutr., 29: 399 (1973).

27. Mann, M. D., Becker, D. J., Pimstone, B. L., and Hansen, J. D. L.: Potassium supplementation, serum immunoreactive insulin concentrations and glucose tolerance in protein-energy malnutrition. Brit. J. Nutr., 33: 55 (1975).

28. Marks, V., Howorth, N., and Greenwood, F. C.: Plasma growth hormone levels in chronic starvation in man. Nature, 208: 686 (1965).

29. Melichar, V., Novak, M., Hahn, P., and Koldovsky, O.: Free fatty acid and glucose in the blood of various groups of newborns. Preliminary Report. Acta Paediat., 53: 343 (1964).

30. Merimee, T. J., Felig, P., Marliss, E., Fineberg, S. E., and Cahill, G. F., Jr.: Glucose and lipid homeostasis in the absence of human growth hormone. J. Clin. Invest., 50: 574 (1971).

31. Milner, R. D. G.: Metabolic and hormonal responses to glucose and glucagon in patients with infantile malnutrition. Pediat. Res., 5: 33 (1971).

32. Milner, R. D. G.: Metabolic and hormonal responses to oral amino acids in infantile malnutrition. Arch. Dis. Childhood, 46: 301 (1971).

33. Milunsky, A., Bray, G. A., Londono, J., and Loridan, L.: Insulin, glucose, growth hormone, and free fatty acids. Determination in patients with cystic fibrosis. Amer. J. Dis. Child., 121: 15 (1971).

34. Mönckeberg, F., Donoso, G., Oxman, S., Pak, N., and Meneghello, J.: Human growth hormone in infant malnutrition. Pediatrics, 31: 58 (1963).

35. Nelson, N.: A photometric adaptation of the Somogyi method for the determination of glucose. J. Biol. Chem., 153: 375 (1944).

36. Parra, A., Garza, C., Garza, Y., Saravia, J. L., Hazelwood, C. F., and Nichols, B. L.: Changes in growth hormone, insulin, and thyroxine values, and in energy metabolism of marasmic infants. J. Pediat., 82: 133 (1973).

37. Pickens, J. M., Burkeholder, J. N., and Womack, W. N.: Oral glucose tolerance test in normal children. Diabetes, 16: 11 (1967).

38. Pimstone, B. L., Barbezat, G., Hansen, J. D. L., and Murray, P.: Growth hormone and protein-calorie malnutrition. Lancet, $i i: 1333$ (1967).

39. Pimstone, B. L., Barbezat, G., Hansen, J. D. L., and Murray, P.: Studies on growth hormone secretion in protein-calorie malnutrition. Amer. J. Clin. Nutr., 21: 482 (1968).
40. Pimstone, B. L., Wittman, W., Hansen, J. D. L., and Murray, P.: Growth hormone and kwashiorkor. Lancet, ii: 779 (1966).

41. Prinsloo, J. G., DeBruin, E. J. P., and Kruger, H.: Comparison of intravenous glucose tolerance tests and serum insulin levels in kwashiorkor and pellagra. Arch. Dis. Childhood, 46: 795 (1971).

42. Raghuramulu, N., and Jaya Rao, K. S.: Growth hormone secretion in protein-calorie malnutrition. J. Clin. Endocrinol. Metab., 38: 176 (1974).

43. Randle, P. J., Garland, P. B., Hales, C. N., and Newsholme, E. A.: The glucose fatty-acid cycle. Its role in insulin sensitivity and the metabolic disturbances of diabetes mellitus. Lancet, $i: 785$ (1963).

44. Samuel, A. M., and Deshpande, U. R.: Growth hormone levels in protein calorie malnutrition. J. Clin. Endocrinol Metab. 35: 863 (1972).

45. Schalch, D. S., and Parker, M. L.: A sensitive double antibody immunoassay for human growth hormone in plasma. Nature, 203: 1141 (1964).

46. Sukkar, M. Y., Hunter, W. M., and Passmore, R.: Changes in plasma levels of insulin and growth hormone levels after a protein meal. Lancet, ii: 1020 (1967).

47. Yalow, R. S and Berson, S. A. Immunoassay of endogenous plasma insulin in man. J. Clin. Invest., 39: $1157(1960)$

48. Zierler, K. L., and Rabinowitz, D.: Effect of very small concentrations of insulin on forearm metabolism. Persistence of its action on potassium and free fatty acids without its effect on glucose. J. Clin. Invest., 43: 950 (1964).

49. Informed consent was obtained for all subjects in this study.

50. This research was supported in part by Research Grants AM-09980 and HD-01852 from the National Institutes of Health, United States Public Health Service, and Research Contract csd-2946 with the Agency for International Development, United States Department of State.

51. The present address of Dr. R. G. Thompson is: Department of Pediatrics, University of Iowa School of Medicine, Iowa City, Iowa.

52. The present address of Dr. R. M. Blizzard is: Department of Pediatrics, University of Virginia School of Medicine, Charlottesville, Virginia.

53. Requests for reprints should be addressed to: George G. Graham, M. D., 615 North Wolfe St., Baltimore, Md. 21205 (USA).

54. Accepted for publication May 7, 1976.

\title{
A Behavioral Phenotype in the de Lange Syndrome
}

\author{
HAROLD G. JOHNSON, PAUL EKMAN, AND WALLACE FRIESEN \\ Human Interaction Laboratory, University of California San Francisco, San Francisco, California
}

WILLIAM L. NYHAN ${ }^{(20)}$

Department of Pediatrics, University of California San Diego, San Diego, California

CAROL SHEAR

Mailman Center, Department of Pediatrics, University of Miami, Miami, Florida, USA

\section{Extract}

The behavior of nine patients with the de Lange syndrome was studied using videotape, a recording protocol of eight standardized stimulus conditions, and a visual, digital time reference which permitted precise coding and quantitative analysis. These patients avoid or reject social interactions and physical contact, and they do not distinguish in this between a stranger and the mother or her substitute. Social interactions with the adult stranger were scored in patients $1-7$ as negative for $28-56 \mathrm{sec} / \mathrm{min}$, whereas they were positive for 1-6 sec/min. Statistical significance was at the level of $P$ $<0.01$. In the case of the mother negative responses ranged from $21-45 \mathrm{sec} / \mathrm{min}$ and positive from 3-27 $\mathrm{sec} / \mathrm{min}$. The patients exhibit infrequent facial expressions of emotion, and frequently display stereotypic movements. On the other hand, vestibular stimulation or vigorous movement appeared to be an effective means of eliciting pleasurable responses. When held in arms in the vertical position only one of nine children smiled at all and the frequency for that child was $0.8 / \mathrm{min}$. When the child was bounced vigorously in the same position, all smiled but one who was too large to be bounced. In the eight the frequency of smiling ranged from 0.8 $3.6 / \mathrm{min}$. The data obtained indicate that a specific behavioral phenotype is associated with this syndrome.

\section{Speculation}

It seems clear that there is a distinct behavioral phenotype in the de Lange syndrome. We believe that this is only one of many such patterns of behavior that characterize children with clinical syndromes. The delineation of these phenotypes should provide important evidence on somatic determinants of behavior. 